\title{
Making a Commitment to Your Future: Investigating the Effect of Career Exploration and Career Decision-Making Self-Efficacy on the Relationship between Career Concern and Career Commitment
}

\author{
Shi Chen ${ }^{1 \oplus}$, Yan Xue ${ }^{2}$, Huaruo Chen ${ }^{1,3}{ }^{\oplus}$, Hairong Ling ${ }^{1}$, Jiajing $W^{4}{ }^{4}$ and Xueying Gu ${ }^{1, *}$ \\ 1 School of Education Science, Nanjing Normal University, Nanjing 210046, China;

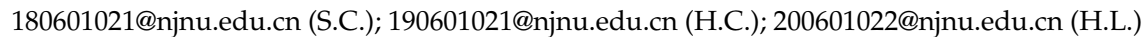 \\ 2 School of Psychology, Nanjing Normal University, Nanjing 210097, China; 02189@njnu.edu.cn \\ 3 Center for Research and Reform in Education, Johns Hopkins University, Baltimore, MA 21286, USA \\ 4 Faculty of Social Science, The Chinese University of Hong Kong, Hong Kong, China; \\ 1155124285@link.cuhk.edu.hk \\ * Correspondence: 02099@njnu.edu.cn; Tel.: +86-139-1301-7319
}

Citation: Chen, S.; Xue, Y.; Chen, H.; Ling, H.; Wu, J.; Gu, X. Making a Commitment to Your Future: Investigating the Effect of Career Exploration and Career Decision-Making Self-Efficacy on the Relationship between Career Concern and Career Commitment. Sustainability 2021, 13, 12816. https://doi.org/10.3390/su132212816

Academic Editors:

Alexandros-Stamatios Antoniou,

Katerina Argyropoulou and

Nikos Drosos

Received: 22 September 2021

Accepted: 16 November 2021

Published: 19 November 2021

Publisher's Note: MDPI stays neutral with regard to jurisdictional claims in published maps and institutional affiliations.

Copyright: (c) 2021 by the authors. Licensee MDPI, Basel, Switzerland. This article is an open access article distributed under the terms and conditions of the Creative Commons Attribution (CC BY) license (https:// creativecommons.org/licenses/by/ $4.0 /)$.

\begin{abstract}
Career commitment refers to individuals' dedication to their career; in the field of vocational psychology, career commitment is considered a vital factor for promoting a sustainable career. The current study examined a mediation model of career concern related to career commitment with career exploration and Career Decision-Making Self-Efficacy (CDMSE) as two mediators. The participants were 1105 high school students (males $=594$, females $=511$ ) recruited from three main cities in Jiangsu Province, China. Results indicated that the hypotheses were all confirmed: the direct effect of career concern on career commitment was significant $(\beta=0.598, p<0.001)$; the indirect effect of career concern on career commitment through career exploration and CDMSE was also significant $(\beta=0.255, p<0.001)$; and career exploration and CDMSE mediated the relation from career concern to career commitment. Finally, the authors discussed the implications of the findings which could be applied to improve a high school student's career commitment and the sustainability of career development. The limitations of the study and the future research needed to complement the current work are also discussed.
\end{abstract}

Keywords: sustainable careers; career concern; career exploration; career decision-making self-efficacy; career commitment; high school students

\section{Introduction}

Under the era of protean and boundaryless career [1], a sustainable career for individuals is considered with making contributions to the personal survival and self-realization value [2]. Sustainable career development refers to "the sequences of an individual's different career experiences, reflected through a variety of patterns of continuity over time, thereby crossing several social spaces, characterized by individual agency, herewith providing meaning to the individual" [3] (p. 7). As a critical period in life, people aged 15-24 years are in the career developmental stage of exploration, while adolescents aged 15-17 years are in the substage called the stage of tentative. The main career developmental task in this substage is to try to make a tentative career decision for one's future vocation, integrally considering one's interests, values, abilities, opportunities, and other personal traits [4]. However, most Chinese high schools still have not established a career intervention system to assist students to promote sustainable career development. Career intervention in Chinese societies faces several challenges including [5]: (i) the lack of indigenous theoretical models for career research and practice; (ii) insufficient scientific assessment instruments for career intervention; (iii) meager professional training and education for researchers, practitioners, educators, and counsellors; and (iv) passive beliefs and attitudes toward career invention among Chinese counsellors and students. 
While facing some tough challenges, Chinese high school students' demand for developing a sustainable career has risen sharply. Moreover, the COVID-19 pandemic brings more changes and difficulties for students in developing sustainable careers [6]. Sustainable career was divided into four aspects, those being time, social space, agency, and meaning, before the pandemic [7]; however, another aspect was added to the sustainability connection to the postpandemic work, suggesting the complexity regarding how the context affects the career decision-making process [8]. Additionally, around some Chinese coastal provinces, a new reform for college entrance examinations was issued in 2018. According to the new reform, high schools should pay more attention to students' sustainable careers. Most high school leaders and teachers are now considering rigorous questions such as 'How can one help students concentrate on career development?' and 'How can one guide students to set career goals and make commitments to achieve these goals?'. To help those educators who are confused about educating high school students in career planning, the current study investigated some Chinese high school students' psychological traits relating to sustainable career development, including career concern, career exploration, CDMSE, and career commitment, and analyzed the relationship between the four variables.

\section{Research Theory and Hypothesis}

\subsection{Career Concern}

From the perspective of sustainable career development, career concern facilitates a career transition into sustainable careers [9]. Career concern is about how individuals look ahead and prepare for what might come next in their career development [10]. It reminds individuals to concentrate on career development tasks and vocational transitions and decision-making in the proximal or distal future [11,12]. Different models of career development such as Social Cognitive Career Theory, Career Construction Theory, and Cognitive Information Process Theory have considered career concern to be planfulness, anticipation, awareness, involvement, and orientation $[10,13,14]$. If an individual lacks career concern, this may reflect career indifference, which reflects planlessness and pessimism about his/her future career [15]. Career concern represents apprehension about managing what an individual considers to be personally important and essential to his/her career development [16]. High school students in China are confronted with several vital career-related tasks. The stress associated with managing these career-related tasks can be considered to be career concern [17]. High school students must deal with their careerrelated tasks in the context of their families, teachers, peers, and their perspectives. In order to attain sustainable career development, high schools must awaken students' career consciousness and guide their concerns on career development [18].

\subsection{Career Commitment}

Due to the longitudinal nature of careers, career commitment would seem to be crucial for an individual's sustainable career development process [19]. Career commitment is a psychological link between people and their occupation, based on their affective reaction to it [20]; it refers to individuals' dedication to their career, profession, or job and has been studied for nearly four decades [21]. Career commitment is also considered as an individual's insistence on achieving his/her career goals [22]. In such an isolated environment resulting from the COVID-19 pandemic, with a lack of traditional career resources, the more developmental chances an individual perceives as available in their present status, the more positive the relationship between sustainable career development and career commitment is [23].

According to many previous studies, motivation factors can affect career commitment. Lin conducted a two-wave survey and found that passion, social support, and perceived self-centered leadership indirectly relate to turnover intention through the full mediation of career commitment [24]. Calling moderately correlated with career commitment, and career commitment was also found to fully mediate the calling-job satisfaction relation [20]. Ahmed investigated the effects of CDMSE on employees' career commitment and found 
that higher CDMSE indicates a higher level of career commitment [25]. It was also found that career exploration was positively related to career commitment [26].

\subsection{Career Exploration}

Career exploration refers to purposive behaviors and cognitions that afford access to information about occupations, jobs, and organizations that were not previously in the stimulus field [27]. It has been viewed as a stage in the sustainable career development process, a person who wants to develop a career plan must engage in exploring career options and vocational preferences as well as making subsequent career choices [28]. Career exploration was separated into two basic parts: self-exploration and environmental exploration [29]. Through self-exploration, individuals can distinguish their personal attributes as interests, values, personality, and abilities and understand who they are and what kind of career they want in the future [30]. Through environmental exploration, individuals gather information related to jobs, organizations, and occupations and make rational career decisions [31]. Researchers maintain that career exploration (in the form of both self-exploration and environmental exploration) plays a vital role for individuals in identifying suitable job opportunities, achieving better employment, and coping with difficulties and challenges in their career transitions [32-34].

It is proven that career exploration is an vital factor that positively affects sustainable career development among teenagers [35]. For high school students, engaging in career exploration would bring up the sustainability of career development [36]. According to some past studies $[26,37,38]$, it is expected that career exploration behaviors positively predict a better sense of CDMSE. In addition, the higher the level of career exploration, the lower the level of career indecision [39]. However, little research has considered the relationship between career exploration and career commitment among Chinese adolescents.

\subsection{Career Decision-Making Self-Efficacy}

Self-efficacy refers to a person's beliefs concerning his/her ability to successfully perform a given task or behavior, it is an vital mechanism of personal agency and positive adaptation across many domains of psychosocial functioning [40]. Taylor and Betz introduced the self-efficacy theory to the field of vocational behavior, and this stimulated a variety of theoretical and empirical studies in the field of vocational psychology [41]. One of the most studied self-efficacy variables in vocational psychology has been CDMSE, which refers to a person's belief in his/her ability to complete career-related tasks [36,42]. Social Cognitive Career Theory (SCCT) was based on social cognitive theory to further delineate the role of CDMSE expectations in vocational behavior [43,44]. SCCT explains the dynamics of internal and external career development factors in individuals; numerous studies using SCCT have indicated that CDMSE plays a significant role in a person's career planning and sustainable career development $[36,45,46]$.

According to some previous studies, CDMSE is affected by personal attributes derived from genetic dispositions and early learning experiences [47-49]. CDMSE is negatively related to career indecision [7], while it is positively related to career adaptability [47] and career exploration [50]. Consistent with the SCCT model, some variables including self-esteem, vocational identity, peer support, vocational outcome expectations, and career indecision have significant effects on CDMSE according to a meta-analytic approach, while gender, race, and career barriers did not have significant effects on CDMSE [51]. A higher level of CDMSE is related to both a more differentiated vocational self-concept and greater engagement with career exploration activities [34]. Studies on the relationships between demographic variables (gender, race, age, and so on) and CDMSE have produced mixed results $[15,52-54]$. These findings indicate that CDMSE plays a significant role in the development of vocational interests, choices, and exploratory behaviors [55]. For high school students, it is crucial to engage in career exploration to promote CDMSE. 


\subsection{Main Purpose and Hypothesis}

The present study intended to examine the relationships among all the above variables, including (i) the relationship between career concern and career commitment; (ii) the relationships among career concern, career exploration, career commitment, and CDMSE; and (iii) the indirect effects in which career concern affects career commitment as mediated by career exploration and CDMSE.

Hypothesis 1 (H1). Career concern would be positively associated with career exploration, CDMSE, and career commitment, respectively.

Hypothesis 2 (H2). Career exploration would be positively connected with CDMSE and career commitment.

Hypothesis 3 (H3). CDMSE would be positively related to career commitment.

Hypothesis 4 (H4). The positive relationship between career concern and career commitment would be mediated via career exploration and CDMSE.

\section{Materials and Methods}

\subsection{Participants and Procedure}

The participants were all 10th grade students from seven senior high schools located in Jiangsu province, China (four high schools in Nanjing City, one high school in Suzhou City, and two high schools in Yangzhou City, respectively). These high schools' leaders were interested in career education, and they considered carrying out career education in their schools during the COVID-19 pandemic. In order to understand the current status of students' career development and find out some feasible approaches to promote high school students' sustainable careers, we selected students from these seven high schools as participants and investigated career concern, career exploration, CDMSE, and career commitment. Informed consent was obtained from all the students. In total, 1105 students were recruited (594 males and 511 females; 139 participants in Suzhou City, 642 participants in Nanjing City, 324 participants in Yangzhou City) in the current study, with a mean age of 16.2 years old (ranging from 15 to 17 years old; $\mathrm{SD}=0.47$ ).

The investigation was conducted at the beginning of the participants' first term of their 10th grade. The study instruments were uploaded to a website established for the current study. First, the schools informed all the participants about this research to attract participants' attention. Then, the participants were assembled in the computer rooms to load on the website to fill the questionnaires. Before they started completing the questionnaires, the researchers explained the meaning and methods of the study, and the students could also ask any questions while they completed the questionnaires. Only when the students finished all items could they submit their data. The study took 10-15 min for each student to complete all questionnaires. Since there were seven high schools, the research team did the work seven times in two weeks. Data from all participants were anonymous, ensuring that accurate responses to the scales and common method variance may be reduced through the use of an anonymous survey [56]. Regular answers and subjects with response time less than 10 min were excluded from the current study, resulting in 1105 valid data, and the response rate was $97.15 \%$. The ethical approval to recruit participants was granted by the authors' departmental ethics committee, and all the questionnaires were completed voluntarily.

\subsection{Instruments}

\subsubsection{Career Adapt-Abilities Scale}

Career concern was measured using one of the subscales from the Career AdaptAbilities Scale (CAAS)-Chinese Version [57,58]. CAAS-Chinese Version was designed to assess the level of individuals' career adaptability; it consists of four subscales with six 
items in each subscale: (i) career concern (e.g., "I'm not going to worry about choosing an occupation until I am out of school"); (ii) career curiosity (e.g., "I know very little about the requirements of jobs"); (iii) career confidence (e.g., "I have so many interests that it is hard to choose just one occupation"); and (iv) career control (e.g., "Choosing a job is something that you do on your own"). Each item was rated using the responses "agree" or "disagree" (the details of Chinese CAAS can be seen in Appendix A, Table A1). A higher score indicates a higher level of career adaptability. Based on the main purpose of the current study, we selected the scale of career concern as the instrument. Career concern subscale could be used to assess the extent to which an individual is oriented to and involved in preparing for the future [57]. The coefficient of the internal consistency of the career concern subscale in the current study was 0.834 .

\subsubsection{Vocational Identity Status Assessment}

We used the Vocational Identity Status Assessment (VISA) to measure participants' career exploration and career commitment [59]. VISA contains three different dimensions of (i) career exploration, (ii) career commitment, and (iii) career reconsideration. Career exploration looks at exploration across the in-breadth careers (e.g., "Casually learning about careers that are unfamiliar to me to find a few to explore further") and in-depth career exploration (e.g., "Identifying my strongest talents as I think about careers"). Career commitment contains items relating to career commitment making (e.g., "I know what kind of work is best for me") and identification with career commitment (e.g., "My career will help me satisfy deeply personal goals"). Career reconsideration considers career self-doubt (e.g., "Thinking about choosing a career makes me feel uneasy") and career flexibility (e.g., "My work interests are likely to change in the future"). The whole scale is composed of thirty items, and each subscale contains ten items. The VISA was revised to be more accessible for Chinese students [60]. Considering the main purpose of the current study, we selected the career exploration subscale and career commitment subscale. Career exploration subscale measures the frequencies of career exploration behaviors performed by students in the last several months, and career commitment subscale measures the extent to which students had committed to a job and the degree of their identification with these commitments [59]. The current form used in the study consisted of 20 items with a five-point Likert-type scale (ranging from "strongly disagree" to "strongly agree") (the details of Chinese VISA can be seen in Appendix B, Table A2). Higher scores indicate greater levels of career exploration and career commitment. The coefficients of the internal consistency of career exploration subscale and career commitment subscale were 0.785 and 0.738 , respectively. The correlation between career exploration and career commitment was $0.538(p<0.001)$

\subsubsection{Career Decision-Making Self-Efficacy Scale-Short Form}

The CDMSE Scale-Short Form [61] was designed to measure an individual's degree of belief that he or she can complete the tasks necessary for making career decisions. CDMSESF revised this scale into a Chinese version [62]. The Chinese version CDMSE-SF contains 25 items about 5 dimensions: (i) self-appraisal, (ii) gathering occupational information, (iii) goal selection, (iv) planning, and (v) problem-solving. It used a five-point Likert-type scale (ranging from "no confidence" to "fully confident"). A higher score indicates a higher degree of confidence in career decision-making (the details of Chinese CDMSE-SF can be seen in Appendix C, Table A3). The coefficient of internal consistency of the whole scale in the current study was 0.814 ; and the coefficient of internal consistency of each subscale was 0.783 (self-appraisal), 0.786 (gathering occupational information), 0.773 (goal selection), 0.809 (planning), and 0.780 (problem solving), respectively. The correlations between all subscales ranged from 0.503 to $0.621(p<0.001)$. 


\subsection{Data Analysis}

Data were analyzed by using SPSS 23.0 (IBM, New York, NY, USA), AMOS 22.0 (BM, New York, NY, USA), and SmartPLS (SmartPLS GmbH, Boenningstedt, Germany) to analyze all the data.

SmartPLS was used to address the impact of common-method variance and the psychometrics of the constructs [63]. SPSS 23.0 was used to obtain the descriptive statistics, correlation analysis, and regression analysis among all variables; it was also used to test the reliability of the three instruments used in the current study.

AMOS 22.0 was used to test the hypothesized structural equation model. We conducted Confirmatory Factor Analysis (CFA) to confirm the data fit of the measurement model with a two-step procedure [64]. While using the SEM, it is important to report the following profile of indices [65,66]: the $\chi^{2}$ (and its degrees of freedom and $p$-values), the Standardized Root Mean square Residual (SRMR), and the Comparative Fit Index (CFI). For a model that fits the data, the $\chi^{2}$ would not be significant, the SRMR would be close or lower to 0.09 , and the CFI would be close or higher to 0.95 .

We also used SPSS Process [67] to test the mediating effect of career exploration and CDMSE. The bootstrap method is more flexible than classical methods which may be analytically intractable or unusable because of a lack of the appropriate assumptions being satisfied [68]. We adopted a bootstrap method (sampling was repeated 5000 times) to construct a $95 \%$ confidence interval for significance testing of mediating effects.

\section{Results}

The present study investigated the relationships between career concern, career exploration, CDMSE, and career commitment. The results of the analyses are presented below.

\subsection{Common-Method Variance Testing}

The data obtained in the current study were all self-reports of the participants, although we used an anonymous survey; however, the impact of common method variance may still exist. As the Harman single-factor (or one-factor) test was criticized for insensitive, Partial Least Squares (PLS) was used in the current study to address the issue of common method variance [63]. This method has been applied in many career studies [21,69]. All items were substantively loaded on corresponding latent constructs, and the convergent validity was assessed through the Average Variance Extracted (AVE). The results were shown in Table 1, and all the AVE values were higher than the critical threshold of 0.5 [70], which means the latent variables in the current model explained on average more than $50 \%$ of the variance of corresponding indicators. Therefore, common method variance did not cause a significant effect on the results of the present study. The data we collected were eligible for further statistical analysis.

Table 1. Psychometrics of the constructs.

\begin{tabular}{cccc}
\hline & Number of Items & Loading Range & AVE \\
\hline Career Concern & 5 & $0.648-0.801$ & 0.584 \\
Career Exploration & 10 & $0.661-0.817$ & 0.627 \\
CDMSE & 25 & $0.598-0.848$ & 0.542 \\
Career Commitment & 10 & $0.631-0.837$ & 0.612 \\
\hline
\end{tabular}

Note: AVE = Average Variance Extracted; CDMSE = Career Decision-Making Self-Efficacy. Convergent Validity: Loading $>0.5$ and AVE $>0.5$.

\subsection{Descriptive Statistics and Correlation Analysis}

Table 2 shows the descriptive statistics and correlations among all variables, including the sample size, means, standard deviations, skewness and kurtosis, and the correlations. The skewness and kurtosis of all variables ranged from -1 to 1 , and all values of the Shapiro-Wilk test were not significant $(p>0.05)$ [71], indicating that all data are normally distributed [12,72]. Results indicated that there were significant positive correlations among 
various variables: career concern and career exploration $(r=0.275, p<0.001)$; career concern and career commitment $(r=0.333, p<0.001)$; career concern and total score of the CDMSE $(r=0.299, p<0.001)$; career exploration and total score of the CDMSE $(r=0.523, p<0.001)$; and career commitment and total score of the CDMSE $(r=0.603, p<0.001)$. With all these significant correlations between variables, the next step was to test the mediator model.

Table 2. Descriptive statistics and correlations $(\mathrm{N}=1105)$.

\begin{tabular}{lcccccccc}
\hline & M & SD & Skewness & Kurtosis & $\mathbf{1}$ & $\mathbf{2}$ & $\mathbf{3}$ & $\mathbf{4}$ \\
\hline 1. Career Concern & 3.75 & 1.335 & -0.552 & 0.427 & - & & & \\
2. Career Exploration & 24.19 & 3.872 & -0.470 & 0.728 & $0.275^{* * *}$ & - & \\
3. CDMSE & 89.12 & 13.831 & -0.153 & 0.791 & $0.299^{* * *}$ & $0.523^{* * *}$ & - \\
4. Career Commitment & 19.08 & 5.212 & -0.036 & -0.401 & $0.333^{* * *}$ & $0.415^{* * *}$ & $0.603^{* * *}$ & - \\
\hline
\end{tabular}

Note: ${ }^{* * *} p<0.001$.

\subsection{Analysis of Mediating Effect}

The measurement model contains one latent variable and eight observed variables (see Figure 1). Figure 1 shows the different path indices from career concern to career exploration to career commitment, career concern to CDMSE to career commitment, career concern to career commitment, and career concern to career exploration to CDMSE to career commitment, respectively. All paths were significant, which means the mediating roles of career exploration and CDMSE on the effect of career concern on career commitment were all significant.

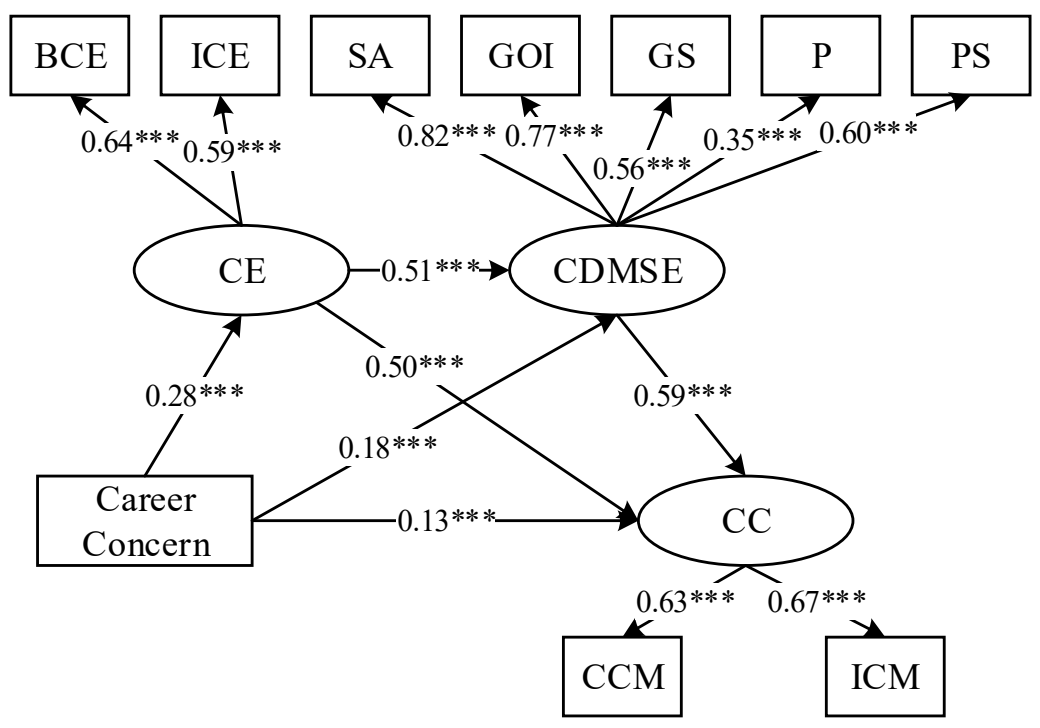

Figure 1. Hypothesized model. Note: $\mathrm{BCE}=$ In-Breadth Career Exploration; $\mathrm{CCM}=$ Career Commitment Making; GOI = Gathering Occupational Information; GS = Goal Setting; ICE = In-depth Career Exploration; ICM = Identification with Career Commitment; $\mathrm{P}=$ Planning; and PS = Problem-Solving; *** $p<0.001$.

The goodness-of-fit indices in Table 3 indicate that the hypothesized model was acceptable [65], as the following indices: $\chi^{2}=80.902, \chi^{2} / \mathrm{df}=4.764, \mathrm{CFI}=0.981$, RMSEA $=0.058$, and SRMR $=0.072$. 
Table 3. Fit indices of the hypothesized model $(\mathrm{N}=1105)$.

\begin{tabular}{|c|c|c|c|c|c|c|}
\hline \multirow{2}{*}{$x^{2}$} & \multirow{2}{*}{ df } & \multirow{2}{*}{$\chi^{2.5 / \mathrm{df}}$} & \multirow{2}{*}{ CFI } & \multicolumn{2}{|c|}{ RMSEA } & \multirow{2}{*}{ SRMR } \\
\hline & & & & Estimate & $90 \%$ CI & \\
\hline 80.902 & 17 & 4.764 & 0.981 & 0.058 & {$[0.046,0.071]$} & 0.072 \\
\hline
\end{tabular}

The mediating effect of career exploration and CDMSE was also found significant. The results in Table 4 show the direct and indirect effects using the bootstrap method. Bootstrap methods are more flexible than classical methods, which may be analytically intractable or unusable because of a lack of the appropriate assumptions being satisfied [68]. We created 5000 bootstrap data samples by randomly sampling with replacement from the original data. The indices (see Table 4) show the mediating effect of career exploration and CDMSE was significant $(p<0.001)$, and the indirect effect was 0.225 .

Table 4. Direct and indirect effects using bootstrapping.

\begin{tabular}{cccc}
\hline Path & DE & IE & 95\% CI \\
\hline Career Concern $\rightarrow$ CC & 0.598 & & {$[0.409,0.789]$} \\
Career Concern $\rightarrow$ CE $\rightarrow$ CC & & 0.121 & {$[0.053,0.205]$} \\
Career Concern $\rightarrow$ CDMSE $\rightarrow$ CC & & 0.326 & {$[0.214,0.451]$} \\
Career Concern $\rightarrow$ CE $\rightarrow$ CDMSE $\rightarrow$ CC & & 0.255 & {$[0.186,0.344]$} \\
\hline
\end{tabular}

Note: $\mathrm{CC}=$ Career Commitment; $\mathrm{CE}=$ Career Exploration; $\mathrm{CI}=$ Confidence Interval; DE = Direct Effect; and IE = Indirect Effect.

\section{Discussion}

This study investigated the relationship between career concern and career commitment among high school students during the COVID-19 pandemic and finally confirmed that high school students' career concern is positively related to career exploration, CDMSE, and career commitment (Hypothesis1); career exploration is positively related to CDMSE and career commitment (Hypothesis 2); and CDMSE is positively related to career commitment (Hypothesis 3). Further results supported the hypothesis that career exploration and CDMSE mediated the relation from career concern to career commitment (Hypothesis 4). The main conclusions and discussions are as follows:

\subsection{Direct Effect of Career Concern on Career Commitment}

The results showed that there is a significant correlation between career concern and career commitment, which was verified in the structural equation model, indicating that career concern has a positive predictive effect on career commitment. This finding is consistent with the results of other researchers [73,74]. It reveals that a high school student with a high level of career concern might hold a firm commitment to his/her career. However, in the analysis of binary correlation, the correlation coefficient was high but relatively lower in the structural equation model. This relationship including the influences of other variables in the multivariate model resulted in an overestimation of the variable relationships. The results of the structural equation model control for multiple influencing factors at the same time, and the estimated value is more accurate. Therefore, after adding career exploration and CDMSE into the structural equation, the influence of career concern on career commitment is weakened by the influence of career exploration and CDMSE, which leads to the disappearance of the direct effect. This result also shows that the effect of career concern on career commitment is likely to be affected by other factors, and the influence mechanism of career concern on career commitment can be tested more accurately and comprehensively by using structural equation modelling. In future studies, it is necessary to further test the influence mechanism of career concern on career commitment with multiple models from different perspectives. 


\subsection{The Mediator Roles of Career Exploration and CDMSE}

It is concluded that career concern can influence career commitment through different paths. After adding career exploration and CDMSE, three different chain mediations were formed. The specific path is as follows:

First, career concern can influence career exploration and career commitment. Career concern can connect career exploration with exploring the external environment and selftraits [75], which in turn, enhance career commitment [76]. Based on the conclusions of the current study, it can be predicted that when individuals form concentration on career, he/she identify self-needs and personal qualities and carry out some relevant environmental exploration; this would play a positive role in making career commitments and further aspects of his/her career development.

Second, career concern can influence the CDMSE and then influence career commitment. Through practice, career concern can promote the important factors of career development as CDMSE, and CDMSE can enhance the positive experience of individuals in terms of their careers and lead to career commitment [77,78]. This reflects the view of the social cognitive career theory that CDMSE is formed by social construction and has a predictive effect on positive career outcomes.

This is consistent with the results of previous studies that have shown that career concern can predict CDMSE $[79,80]$. The more confident individuals are in their career choice and commitment, the more likely they are to be satisfied with their careers. Therefore, it can be concluded that when individuals can recognize the opportunity for changes and self-regulation, they can improve their self-confidence in career commitment, and the improvement of career commitment leads to positive cognitions and evaluation relating to many aspects of their career development.

Third, career concern can influence career exploration and CDMSE and then affect career commitment. Career concern can realize career commitment through the chain mediation of CDMSE and career exploration. Career concern essentially means a future orientation, a sense that it is important to prepare for tomorrow [81]. The results of this study show that a good career concern has a positive effect on an individual's career exploration ability, thus promoting individual CDMSE and career commitment. In the comparison of individual mediating effects of multiple mediating models, the individual mediating effects of CDMSE are significantly greater than the other individual mediating effects. The explanation for this result is that self-efficacy is an important explanatory variable with the same ability level but different performance results.

As the CDMSE (which reflects the degree of self-confidence in the process of career commitment) affects the individual's scheduling of career commitment, it is an important collaborative decision-maker of career concern on career commitment. Based on the above analysis, it can be concluded that the influence of career concern as an independent variable on career commitment can be through behavior (Career Exploration) and cognition (CDMSE). In other words, when the individual has the social-psychological capital of career concern, this makes the individual more confident in self-efficacy, demonstrate more exploration, commitment, and other behaviors, and then promote the individual to obtain stronger feelings of career success.

\subsection{Implications for Practice}

The huge impacts of the COVID-19 pandemic have already brought career shocks to many people [82], and some Chinese high school students were confused about their career development [36]. As a result, high school students and teachers paid more attention to the career interventions to promote the sustainability of career development and finally guide high school students to make a commitment to the future career. Our findings suggest that high school students' career commitment can be enhanced through three different approaches, which would enlighten the Chinese career educators, counsellors, and researchers to design a more efficient career intervention system for high school students to promote the sustainability of career development. A meta-analysis show that 
career interventions have positive effects on individual' career development (average effect size $=0.452)$ [54]. However, integral, systematic, and long-period career interventions cannot be carried out in most Chinese high schools by now. For example, most Chinese high schools can only provide career courses of 6-8 classes in one semester, and the number in Taiwan and Hongkong is 18-20. Especially during the period of the pandemic, as a result of lockdown and social distancing, career courses in many Chinese high schools were reformed with a blended learning approach for sustaining quality teaching and studying. Therefore, the effect of career interventions must be maximized within limited resources, which requires the career intervention to be focused, targeted, and purposeful. Additionally, career interventions in high schools must implement the tendency to reflect on nowadays and future challenges to be able to improve high school students' sustainability on career development [83]. Based on the findings, we suggested some practical solutions improve current Chinese high schools' career intervention during the pandemic.

First, high school students' concern for career development should be increased urgently. Most high school freshmen in China did not engage in career intervention or career education in the period of middle schools and preliminary schools, and most of their parents seldom talk with them about career development and career planning, parents care more about academic scores. As a result, even these high school students are 15 years old which at the stage of career exploration, they seldom consider their future career and lack of career readiness; career intervention seems a strange thing to them [38]. For this reason, career educators and counsellors must awaken high school freshmen's awareness about their career at the beginning of the first term. For example, high schools could carry out one or two lectures and invite some graduates to share their experience about planning career. The topic of the first career course should also be designed to let the students deeply consider career development, and some narrative approach could be used as writing about future plans on the paper [84].

Regarding the significant mediating effects, career exploration and CDMSE show crucial effects on the promotion of career commitment. More specifically, the positive mediating effect of career exploration on the relationship between career concern and career commitment reveals that high schools students' self-exploration and environmental exploration are essential. Based on this view, high schools should give correct guidance to students as they explore self (e.g., interests, work values, personalities, career development status, and vocational identity) and environment (e.g., social support, jobs, majors, and organizations) [85]. To explore self, career assessment would be a practicable approach [86]. Both quantitative career assessment and qualitative career assessment are available for students. The use of quantitative and qualitative career assessment in career intervention both serve their purpose and that career intervention would benefit from a multistoried progress that addresses the complex contexts within which individual career development takes place $[87,88]$. Computer-Assisted Career Guidance Systems (CACGS) are popular around the world, and almost every CACGS contains career assessments that could be used by individuals to do self-exploration [89,90]. Some Chinese researchers and institutions have developed some CACGS for high school students; hence, we consider these CACGS could be introduced to high schools to enhance high school students' career sustainability. Moreover, career educators and counselors should help students become involved in more environmental exploratory activities such as visiting universities, colleges, factories, or other main organizations. In addition, students with lower level of career exploration scores or CDMSE scores are recommended to seek individual career counselling.

Through these approaches, the career commitment of high school students could be gradually improved, so that high school students have the consciousness and ability to independently plan their sustainable careers. In the high school period, students should establish career goals, clarify career direction, master career methods, perform career planning, and learn to adapt, completing all the career-related tasks would contribute to sustainable career development. 


\subsection{Limitations and Future Research Design}

Although some progress and findings were made in our research, there are still several limitations to this research, which may have negative impacts on the authenticity and effectiveness of the results. Therefore, in the subsequent studies, we should try to make up for these vulnerabilities.

From the perspective of the recruitment of research participants, they are all from Jiangsu Province. Jiangsu Province is one of the provinces in China, and its economic aggregate, cultural heritage, and education level are among the highest in the whole country. Thus, to a certain extent, students in Jiangsu province cannot be considered representative of students from all over China, especially those in poor areas such as Guangxi, Guizhou, Yunnan, and so on. Students in Jiangsu differ from students in poor provinces in some ways. In addition, the participants recruited in this study were also from the best high schools in Jiangsu Province, and there are also some differences and gaps between the superior high schools and common high schools. Thus, in future research, the range of the research participants should be expanded to cover students from more provinces and different school levels in China.

There is another drawback to the selection of the research participants; that is, the participants were all grade 10 students, and no students were recruited from the 11th and 12th grades. In theory, students of different ages and different grades perform diversely in their career behaviors. In particular, the research was conducted at the beginning of grade 10, which means students had received little education at the high school level. In future research, the researchers should recruit more senior students to achieve a balance between grades.

The study approach may be associated with another potential problem. When exploring the relationship between each variable, we did not fully consider the demographic variables of the participants, such as gender, race, family SES (socioeconomic status), academic level, and so on. Some studies have shown that gender has an impact on career concern [91], career exploration [92], and also career commitment [93]; high/low family SES also has an impact on such variables $[85,94]$. In future research, we should consider the effects of the demographic variables of participants on the research findings to provide and perform a higher external validity.

Finally, this study only makes a model-based deduction focusing on career concern, career exploration, career commitment, and CDMSE, and, as such, is at this stage, only theoretical. In future research, it is necessary to further verify the model through intervention to obtain further empirical support.

\section{Conclusions}

The results of the current study illustrate that career exploration and CDMSE play mediator roles in the relationship between career concern and career commitment. As for the high school students, it is important and necessary to awaken their career consciousness and guide their concentration on sustainable career development especially under the circumstance of the COVID-19 pandemic. To further promote high school students' career commitment, it is a possible approach for high schools to provide career intervention as career assessment, career education, and career counseling to enhance students' career exploration and CDMSE. All four variables are vital for young high school students for developing a sustainable career, which is the main purpose of career intervention around high schools.

Author Contributions: S.C. and X.G. conceptualized the work and ideated the structure; X.G. and Y.X. collected the data; H.L. and H.C. did the statistical analyses; S.C. and X.G. interpreted the outcomes and wrote the paper. Y.X. and J.W. provided the study materials; X.G. provided the financial support for the project leading to this publication. All authors have read and agreed to the published version of the manuscript. 
Funding: This research was funded by Jiangsu Province University's Advantageous Discipline Construction Project, grant number "PAPD"; Research on the connection of career education between colleges and middle schools under the background of new college entrance examination, grant number "20jycy20"; Excellent counselor work project of Nanjing Normal University in 2020, grant number "2020JPXM01009".

Institutional Review Board Statement: The study was approved by the Ethics Review Committee of Nanjing Normal University. Ethic Committee Name: Ethics Review Committee of Nanjing Normal University; Approval Code: NNU202105150014; Approval Date: 15 May 2021.

Informed Consent Statement: Informed consent was obtained from all individual participants included in the study.

Data Availability Statement: The data that support the findings of this study are available from the corresponding author. Restrictions apply to the availability of these data, which were used under license for this study. Data are available from the authors with the permission of Nanjing Normal University.

Conflicts of Interest: The authors declare no conflict of interest.

\section{Appendix A}

Table A1. Career Adaptability Scale.

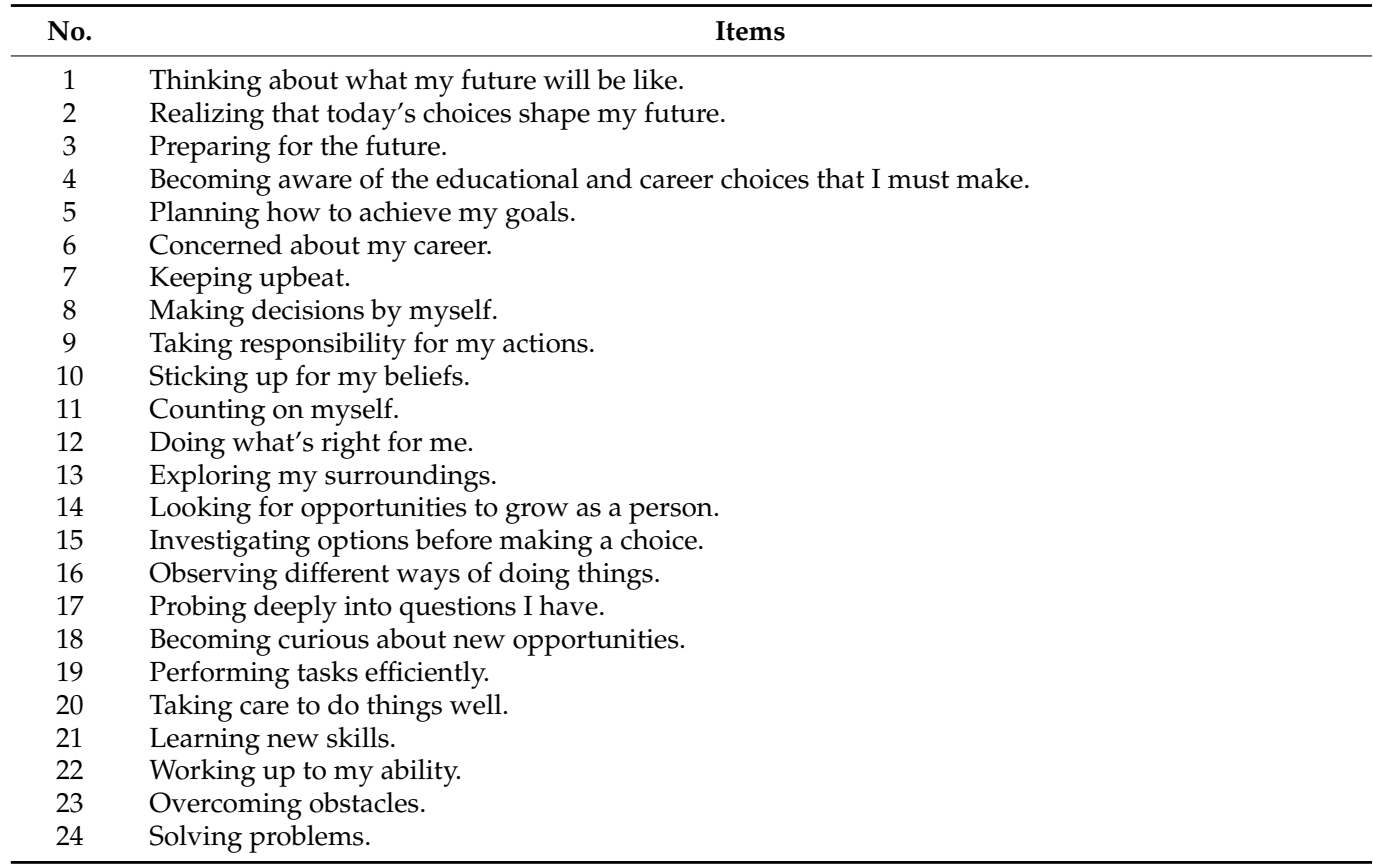

\section{Appendix B}

Table A2. Vocational Identity Status Assessment.

\begin{tabular}{cl}
\hline No. & \multicolumn{1}{c}{ Items } \\
\hline 1 & Casually learning about careers that are unfamiliar to me in order to find a few to explore further. \\
2 & Trying to have many different experiences so that I can find several jobs that might suit me. \\
3 & Thinking about how I could fit into many different careers. \\
4 & Learning about various jobs that I might like. \\
5 & Keeping my options open as I learn about many different careers. \\
6 & Identifying my strongest talents as I think about careers. \\
7 & Learning as much as I can about the particular educational requirements of the career that interests \\
& me the most.
\end{tabular}


Table A2. Cont.

\begin{tabular}{cl}
\hline No. & \multicolumn{1}{c}{ Items } \\
\hline 8 & Learning what I can do to improve my chances of getting into my chosen career. \\
9 & Trying to find people that share my career interests. \\
10 & Thinking about all the aspects of working that are important to me. \\
11 & I know what kind of work is best for me. \\
12 & No other career is as appealing to me as the one I expect to enter. \\
13 & I have known for a long time what career is best for me. \\
14 & No one will change my mind about the career I have chosen. \\
15 & I have invested a lot of energy into preparing for my chosen career. \\
16 & My career will help me satisfy deeply personal goals. \\
17 & My family feels confident that I will enter my chosen career. \\
18 & Becoming a worker in my chosen career will allow me to become the person I dream to \\
19 & be. \\
20 & My chose a career that will allow me to remain true to my values. \\
21 & Thinking about choosing a career makes me feel uneasy. \\
22 & When I tell other people about my career plans, I feel like I am being a little dishonest. \\
23 & People who really know me seem doubtful when I share my career plans with them. \\
24 & I doubt I will find a career that suits me. \\
25 & I may not be able to get the job I really want. \\
26 & My work interests are likely to change in the future \\
27 & What I look for in a job will change in the future. \\
28 & I will probably change my career goals. \\
29 & My career choice might turn out to be different than I expect. \\
30 & I need to learn a lot more before I can make a career choice. \\
\hline
\end{tabular}

\section{Appendix C}

Table A3. Career Decision-Making Self-efficacy Scale—Short Form.

\begin{tabular}{cl}
\hline No. & \multicolumn{1}{c}{ Items } \\
\hline 1 & Change majors if you did not like your first choice. \\
2 & Change occupations if you are not satisfied with the one you enter. \\
3 & Identity some major or career alternatives if you are unable to get your first choice. \\
4 & Find information about graduate or professional schools. \\
5 & Determine steps to take if you are having academic trouble with your major \\
6 & Make a career decision and then not worry if it was right or wrong. \\
7 & Figure out what you are or are not ready to sacrifice for your career goals. \\
8 & Find out employments trends for an occupation over the next 10 years. \\
9 & Prepare a good resume. \\
10 & Successfully manage the job interview process. \\
11 & Make a plan of your goals for the next 5 years. \\
12 & Accurately assess your abilities. \\
13 & Determine the steps you need to successfully complete your chosen majors. \\
14 & Identify employers relevant to your career possibilities. \\
15 & Persistently works at your major or career goal even when you get frustrated. \\
16 & Choose a major or career that will fit your interests. \\
17 & Select one occupation from a list of potential occupations you are considering. \\
18 & Find the average yearly earning of people in an occupation. \\
19 & Determine what your ideal job would be. \\
20 & Choose a career that will fit your preferred lifestyle. \\
22 & Select one major from a list you are considering. \\
23 & Determine the kind of information about occupation that interest you. \\
24 & Talk with a person already employed in a field you are interested in. \\
25 & Decide what you value most in an occupation. \\
\hline
\end{tabular}




\section{References}

1. Kundi, Y.M.; Hollet-Haudebert, S.; Peterson, J. Linking Protean and Boundaryless Career Attitudes to Subjective Career Success: A Serial Mediation Model. J. Career Assess. 2021, 29, 263-282. [CrossRef]

2. Kiani, A.; Liu, J.; Ghani, U.; Popelnukha, A. Impact of future time perspective on entrepreneurial career intention for individual sustainable career development: The roles of learning orientation and entrepreneurial passion. Sustainability 2020, $12,3864$. [CrossRef]

3. Van der Heijden, B.I.J.M.; De Vos, A. Sustainable Careers: Introductory Chapter. In Handbook of Research on Sustainable Careers; Edward Elgar: Cheltenham, UK, 2015; pp. 1-19. [CrossRef]

4. Gebbels, M.; Pantelidis, I.S.; Goss-Turner, S. Conceptualising patterns of career commitment: The leaving process in hospitality. Int. J. Contemp. Hosp. Manag. 2020, 32, 126-147. [CrossRef]

5. Fan, W.; Leong, F.T.L. Introduction to the Special Issue: Career Development and Intervention in Chinese Contexts. Career Dev. $Q$. 2016, 64, 192-202. [CrossRef]

6. Lau, S.S.S.; Wan, K.; Tsui, M. Evaluation of a blended career education course during the COVID-19 pandemic on students' career awareness. Sustainability 2021, 13, 3471. [CrossRef]

7. Park, I.J.; Gu, M.; Hai, S. How can personality enhance sustainable career management? The mediation effects of future time perspective in career decisions. Sustainability 2020, 12, 1167. [CrossRef]

8. Chudzikowski, K.; Gustafsson, S.; Tams, S. Constructing alignment for sustainable careers: Insights from the career narratives of management consultants. J. Vocat. Behav. 2020, 117, 103312. [CrossRef]

9. Ruiz Castro, M.; Van der Heijden, B.; Henderson, E.L. Catalysts in career transitions: Academic researchers transitioning into sustainable careers in data science. J. Vocat. Behav. 2020, 122, 103479. [CrossRef]

10. Baginski, S.P.; Campbell, J.L.; Hinson, L.A.; Koo, D.S. Do care, er concerns affect the delay of bad news disclosure? Account. Rev. 2018, 93, 61-95. [CrossRef]

11. Garcia, P.R.J.M.; Restubog, S.L.D.; Ocampo, A.C.; Wang, L.; Tang, R.L. Role modeling as a socialization mechanism in the transmission of career adaptability across generations. J. Vocat. Behav. 2019, 111, 39-48. [CrossRef]

12. Shin, Y.J.; Lee, J.Y. Self-Focused Attention and Career Anxiety: The Mediating Role of Career Adaptability. Career Dev. Q. 2019, 67, 110-125. [CrossRef]

13. Savickas, M. Life design: A paradigm for career intervention in the 21st century. J. Couns. Dev. 2012, 90, 13-19. [CrossRef]

14. Hayden, S.C.W.; Osborn, D.S.; Peace, C.; Lange, R. Enhancing agency in career development via cognitive information processing theory. Br. J. Guid. Couns. 2021, 49, 304-315. [CrossRef]

15. Rudolph, C.W.; Lavigne, K.N.; Zacher, H. Career adaptability: A meta-analysis of relationships with measures of adaptivity, adapting responses, and adaptation results. J. Vocat. Behav. 2017, 98, 17-34. [CrossRef]

16. Potgieter, I.L.; Coetzee, M.; Ferreira, N. The role of career concerns and workplace friendship in the job embeddedness-retention practices satisfaction link. SA J. Ind. Psychol. 2018, 44, 9. [CrossRef]

17. Marciniak, J.; Johnston, C.S.; Steiner, R.S.; Hirschi, A. Career Preparedness Among Adolescents: A Review of Key Components and Directions for Future Research. J. Career Dev. 2020, 1-23. [CrossRef]

18. Xu, C.; Gong, X.; Fu, W.; Xu, Y.; Xu, H.; Chen, W.; Li, M. The role of career adaptability and resilience in mental health problems in Chinese adolescents. Child Youth Serv. Rev. 2020, 112, 104893. [CrossRef]

19. Zhu, D.; Kim, P.B.; Milne, S.; Park, I.J. A Meta-Analysis of the Antecedents of Career Commitment. J. Career Assess. 2020, 29, 502-524. [CrossRef]

20. Jia, Y.; Hou, Z.J.; Wang, D. Calling and career commitment among Chinese college students: Career locus of control as a moderator. Int. J. Educ. Vocat. Guid. 2020, 21, 211-230. [CrossRef]

21. Huang, W.; Yuan, C.; Li, M. Person-job fit and innovation behavior: Roles of job involvement and career commitment. Front. Psychol. 2019, 10, 1134. [CrossRef]

22. Wickramasinghe, V. The mediating effect of job stress in the relationship between work-related dimensions and career commitment. J. Heal. Organ. Manag. 2016, 30, 408-420. [CrossRef]

23. Wong, S.I.; Kost, D.; Fieseler, C. From crafting what you do to building resilience for career commitment in the gig economy. Hum. Resour. Manag. J. 2021, 31, 918-935. [CrossRef]

24. Lin, C.P. Exploring career commitment and turnover intention of high-tech personnel: A socio-cognitive perspective. Int. J. Hum. Resour. Manag. 2020, 31, 760-784. [CrossRef]

25. Ahmed, N.O.A. Career commitment: The role of self-efficacy, career satisfaction and organizational commitment. World J. Entrep. Manag. Sustain. Dev. 2017. [CrossRef]

26. Wong, Z.Y.; Kaur, D. The role of vocational identity development and motivational beliefs in undergraduates' student engagement. Couns. Psychol. Q. 2018, 31, 294-316. [CrossRef]

27. Cheung, R.; Jin, Q. Impact of a Career Exploration Course on Career Decision Making, Adaptability, and Relational Support in Hong Kong. J. Career Assess. 2016, 24, 481-496. [CrossRef]

28. Chasanah, A.M.; Salim, R.M.A. Parental Support, Career Exploration, and Career Decision-Making Self-Efficacy in Junior High School Students. ANIMA Indones. Psychol. J. 2019, 34, 211-221. [CrossRef]

29. Ali, S.R.; Pham, A.; Loh Garrison, Y.; Brown, S.D. Project HOPE: Sociopolitical Development and SCCT Beliefs of Latinx and White Rural Middle School Students. J. Career Dev. 2018, 46, 410-424. [CrossRef] 
30. Rogers, M.E.; Creed, P.A. A longitudinal examination of adolescent career planning and exploration using a social cognitive career theory framework. J. Adolesc. 2011, 34, 163-172. [CrossRef]

31. Chin, M.Y.; Blackburn Cohen, C.A.; Hora, M.T. Examining US business undergraduates' use of career information sources during career exploration. Educ. Train. 2019, 62, 15-30. [CrossRef]

32. Gilliam, R.; Talpade, M. An Exploration of the Roles, Goals, and Social Interactions of Ghanaian Women. J. Student Res. 2021, 10, 1. [CrossRef]

33. Hu, S.; Hood, M.; Creed, P.A.; Shen, X. The Relationship Between Family Socioeconomic Status and Career Outcomes: A Life History Perspective. J. Career Dev. 2020. [CrossRef]

34. Ireland, G.W.; Lent, R.W. Career exploration and decision-making learning experiences: A test of the career self-management model. J. Vocat. Behav. 2018, 106, 37-47. [CrossRef]

35. Jiang, Z.; Newman, A.; Le, H.; Presbitero, A.; Zheng, C. Career exploration: A review and future research agenda. J. Vocat. Behav. 2019, 110, 338-356. [CrossRef]

36. Chen, S.; Chen, H.; Ling, H.; Gu, X. How do students become good workers? Investigating the impact of gender and school on the relationship between career decision-making self-efficacy and career exploration. Sustainability 2021, 13, 7876. [CrossRef]

37. Lau, P.L.; Chung, Y.B.; Wang, L. Effects of a Career Exploration Intervention on Students' Career Maturity and Self-Concept. J. Career Dev. 2019, 48, 311-324. [CrossRef]

38. Gu, X.; Tang, M.; Chen, S.; Montgomery, M.L.T. Effects of a Career Course on Chinese High School Students' Career DecisionMaking Readiness. Career Dev. Q. 2020, 68, 222-237. [CrossRef]

39. Denault, A.S.; Ratelle, C.F.; Duchesne, S.; Guay, F. Extracurricular activities and career indecision: A look at the mediating role of vocational exploration. J. Vocat. Behav. 2019, 110, 43-53. [CrossRef]

40. Peura, P.; Aro, T.; Räikkönen, E.; Viholainen, H.; Koponen, T.; Usher, E.L.; Aro, M. Trajectories of change in reading self-efficacy: A longitudinal analysis of self-efficacy and its sources. Contemp. Educ. Psychol. 2021, 64, 101947. [CrossRef]

41. Taylor, K.M.; Betz, N.E. Applications of self-efficacy theory to the understanding and treatment of career indecision. J. Vocat. Behav. 1983, 22, 63-81. [CrossRef]

42. Park, I.J.; Rie, J.; Kim, H.S.; Park, J. Effects of a Future Time Perspective-Based Career Intervention on Career Decisions. J. Career Dev. 2020, 47, 96-110. [CrossRef]

43. Halim, L.; Rahman, N.A.; Wahab, N.; Mohtar, L.E. Factors influencing interest in STEM careers: An exploratory factor analysis. Asia-Pac. Forum Sci. Learn. Teach. 2018, 19, 1-34.

44. Sheu, H.-B.; Bordon, J.J. SCCT Research in the International Context: Empirical Evidence, Future Directions, and Practical Implications. J. Career Assess. 2017, 25, 58-74. [CrossRef]

45. Wendling, E.; Sagas, M. An Application of the Social Cognitive Career Theory Model of Career Self-Management to College Athletes' Career Planning for Life After Sport. Front. Psychol. 2020, 11, 9. [CrossRef] [PubMed]

46. Xin, L.; Tang, F.; Li, M.; Zhou, W. From school to work: Improving graduates' career decision-making self-efficacy. Sustainability 2020, 12, 804. [CrossRef]

47. Hou, C.; Wu, Y.; Liu, Z. Career decision-making self-efficacy mediates the effect of social support on career adaptability: A longitudinal study. Soc. Behav. Pers. 2019, 47,1-13. [CrossRef]

48. Kvasková, L.; Almenara, C.A. Time Perspective and Career Decision-Making Self-Efficacy: A Longitudinal Examination Among Young Adult Students. J. Career Dev. 2021, 48, 229-242. [CrossRef]

49. Wu, S.; Zhang, K.; Zhou, S.; Chen, W. Personality and career decision-making self-efficacy of students from poor rural areas in China. Soc. Behav. Pers. 2020, 48, 5. [CrossRef]

50. Wang, J.; Fan, W.; Cheung, F.M.; Wang, Q.; Li, M. Personality and Chinese adolescents' career exploration: The mediation effects of self-efficacy and perceived parental support. J. Pacific Rim Psychol. 2019, 13, e28. [CrossRef]

51. Penn, L.T.; Lent, R.W. The Joint Roles of Career Decision Self-Efficacy and Personality Traits in the Prediction of Career Decidedness and Decisional Difficulty. J. Career Assess. 2019, 27, 457-470. [CrossRef]

52. Yusoff, N.R.; Binti, N.; Mahfar, M.B.; Saud, M.S. Bin A review of social career cognitive theory (SCCT) for career decision self-efficacy (CDSE). Int. J. Eng. Adv. Technol. 2019, 8, 808-817. [CrossRef]

53. Bolat, N.; Odac1, H. High School Final Year Students' Career Decision-Making Self-Efficacy, Attachment Styles and Gender Role Orientations. Curr. Psychol. 2017, 36, 252-259. [CrossRef]

54. Whiston, S.C.; Li, Y.; Goodrich Mitts, N.; Wright, L. Effectiveness of career choice interventions: A meta-analytic replication and extension. J. Vocat. Behav. 2017, 100, 175-184. [CrossRef]

55. Ozlem, U.K. The effects of career interventions on university students' levels of career decision-making self-efficacy: A metaanalytic review. Aust. J. Career Dev. 2019, 28, 223-233. [CrossRef]

56. Helm, R.; Conrad, D. The impact of customer-specific and market-related variables on the preference for highly innovative products. Rev. Manag. Sci. 2015, 9, 61-88. [CrossRef]

57. Savickas, M.L.; Porfeli, E.J. Career Adapt-Abilities Scale: Construction, reliability, and measurement equivalence across 13 countries. J. Vocat. Behav. 2012, 80, 661-673. [CrossRef]

58. Hou, Z.J.; Leung, S.A.; Li, X.; Li, X.; Xu, H. Career Adapt-Abilities Scale-China Form: Construction and initial validation. J. Vocat. Behav. 2012, 80, 686-691. [CrossRef] 
59. Porfeli, E.J.; Lee, B.; Vondracek, F.W.; Weigold, I.K. A multi-dimensional measure of vocational identity status. J. Adolesc. 2011, 34, 853-871. [CrossRef]

60. Zhang, J.; Chen, G.; Yuen, M. Validation of the Vocational Identity Status Assessment (VISA) Using Chinese Technical College Students. J. Career Assess. 2019, 27, 675-692. [CrossRef]

61. Betz, N.E.; Klein, K.L.; Taylor, K.M. Evaluation of a short form of the career decision-making self-efficacy scale. J. Career Assess. 1996, 4, 47-57. [CrossRef]

62. Creed, P.A.; Wong, O.Y.; Hood, M. Career decision-making, career barriers and occupational aspirations in Chinese adolescents. Int. J. Educ. Vocat. Guid. 2009, 9, 189-203. [CrossRef]

63. Hair, J.F.; Hult, G.T.M.; Ringle, C.M.; Sarstedt, M. Structural Equation Modeling With Partial Least Squares Path Modeling. In $A$ Primer on Partial Least Squares Structural Equation Modeling (PLS-SEM), 2nd ed.; Sage: California, USA, 2016 ; pp. 127-135.

64. Lewis, T.F. Evidence regarding the internal structure: Confirmatory factor analysis. Meas. Eval. Couns. Dev. 2017, 50, 239-247. [CrossRef]

65. Zhou, L.; Wang, M.; Zhang, Z. Intensive Longitudinal Data Analyses With Dynamic Structural Equation Modeling. Organ. Res. Methods 2021, 24, 219-250. [CrossRef]

66. Jak, S.; Cheung, M.W.L. Meta-analytic structural equation modeling with moderating effects on SEM Parameters. Psychol. Methods 2020, 25, 430-455. [CrossRef] [PubMed]

67. George, D.; Mallery, P. IBM SPSS Statistics Processes for PC. In IBM SPSS Statistics 26 Step by Step; Routledge: Oxfordshire, UK, 2020; pp. 8-25.

68. Lopes, M.E.; Wang, S.; Mahoney, M.W. A bootstrap method for error estimation in randomized matrix multiplication. J. Mach. Learn. Res. 2019, 20, 1434-1473.

69. Ren, S.; Chadee, D. Influence of work pressure on proactive skill development in China: The role of career networking behavior and Guanxi HRM. J. Vocat. Behav. 2017, 98, 152-162. [CrossRef]

70. Fornell, C.; Larcker, D.F. Evaluating Structural Equation Models with Unobservable Variables and Measurement Error. J. Mark. Res. 1981, 18, 39-50. [CrossRef]

71. Hanusz, Z.; Tarasińska, J. Normalization of the Kolmogorov-Smirnov and Shapiro-Wilk tests of normality. Biom. Lett. 2015, 52, 85-93. [CrossRef]

72. Ulas-Kilic, O.; Peila-Shuster, J.J.; Demirtas-Zorbaz, S.; Kizildag, S. Career decision-making self-efficacy of young adolescent students in Turkey. Int. J. Sch. Educ. Psychol. 2020, 8, 38-48. [CrossRef]

73. Najib, H.H.M.; Aljanabi, A. The Mediation Role of Career Adaptability between Career Commitment and Career Motivation: An Empirical Investigation. Inf. Manag. Bus. Rev. 2020, 12, 27-40. [CrossRef]

74. Omar, S.; Tajudeen, F.P. The Influence of Career Adaptability and Career Commitment to Minimize Intention to Leave Among ICT Professionals. Int. J. Hum. Cap. Inf. Technol. Prof. 2020, 11, 23-38. [CrossRef]

75. Li, Y.; Guan, Y.; Wang, F.; Zhou, X.; Guo, K.; Jiang, P.; Mo, Z.; Li, Y.; Fang, Z. Big-five personality and BIS/BAS traits as predictors of career exploration: The mediation role of career adaptability. J. Vocat. Behav. 2015, 89, 39-45. [CrossRef]

76. Batool, S.S.; Ghayas, S. Process of career identity formation among adolescents: Components and factors. Heliyon 2020, 6, e04905. [CrossRef] [PubMed]

77. Trice, T.L. Time of Career Commitment: A Social Cognitive Investigation Of Law Enforcement Officers and The Relationship Between Work-Family Conflict, Time of Career Commitment, Core-Self Evaluations and Affective Organizational Commitment; Webster University: Webster Groves, MO, USA, 2016; p. 76.

78. Almutairi, Y.M.N. Leadership Self-Efficacy and Organizational Commitment of Faculty Members: Higher Education. Adm. Sci. 2020, 10, 66. [CrossRef]

79. Deas, A.; Coetzee, M. Psychological contract, career concerns, and retention practices satisfaction of employees: Exploring interaction effects. Curr. Psychol. 2020, 39, 1990-1998. [CrossRef]

80. Taber, B.J.; Blankemeyer, M. Future work self and career adaptability in the prediction of proactive career behaviors. J. Vocat. Behav. 2015, 86, 20-27. [CrossRef]

81. Savickas, M.L.; Porfeli, E.J. Revision of the career maturity inventory: The adaptability form. J. Career Assess. 2011, 19, 355-374. [CrossRef]

82. Rudolph, C.W.; Zacher, H. COVID-19 and careers: On the futility of generational explanations. J. Vocat. Behav. 2020, 119, 103433. [CrossRef]

83. Di Maggio, I.; Ginevra, M.C.; Santilli, S.; Nota, L.; Soresi, S. The Role of Career Adaptability, the Tendency to Consider Systemic Challenges to Attain a Sustainable Development, and Hope to Improve Investments in Higher Education. Front. Psychol. 2020, 11, 1926. [CrossRef]

84. McWhirter, E.H.; Rojas-Araúz, B.O.; Ortega, R.; Combs, D.; Cendejas, C.; McWhirter, B.T. ALAS: An Intervention to Promote Career Development Among Latina/o Immigrant High School Students. J. Career Dev. 2019, 46, 608-622. [CrossRef]

85. Guan, Y.; Wang, F.; Liu, H.; Ji, Y.; Jia, X.; Fang, Z.; Li, Y.; Hua, H.; Li, C. Career-specific parental behaviors, career exploration and career adaptability: A three-wave investigation among Chinese undergraduates. J. Vocat. Behav. 2015, 86, 95-103. [CrossRef]

86. Rottinghaus, P.J.; Falk, N.A.; Park, C.J. Career Assessment and Counseling for STEM: A Critical Review. Career Dev. Q. 2018, 66, 2-34. [CrossRef] 
87. Sampson, J.P.; Peterson, G.W.; Osborn, D.S.; Hayden, S.C.W. Using career theory to integrate qualitative and quantitative career assessment. In Career Assessment: Qualitative Approaches; Sense Publishers: Rotterdam, The Netherlands, 2015; pp. 181-190; ISBN 9789463000345.

88. McMahon, M.; Watson, M.; Lee, M.C.Y. Qualitative career assessment: A review and reconsideration. J. Vocat. Behav. 2019, 110, 420-432. [CrossRef]

89. Nota, L.; Santilli, S.; Soresi, S. A Life-Design-Based Online Career Intervention for Early Adolescents: Description and Initial Analysis. Career Dev. Q. 2016, 64, 4-19. [CrossRef]

90. Galliott, N. Online Career Guidance: Does Knowledge Equate to Power for High School Students? J. Psychol. Couns. Sch. 2017, 27, 190-207. [CrossRef]

91. Jahng, K.E.; Kim, D. College Students' Adult Attachment and Career Adaptability: Mediation by Maladaptive Perfectionism and Moderation by Gender. J. Career Dev. 2021, 48, 507-520. [CrossRef]

92. Nagib, W.; Wilton, R. Gender matters in career exploration and job-seeking among adults with autism spectrum disorder: Evidence from an online community. Disabil. Rehabil. 2020, 42, 2530-2541. [CrossRef] [PubMed]

93. Katz, I.M.; Rudolph, C.W.; Zacher, H. Age and career commitment: Meta-analytic tests of competing linear versus curvilinear relationships. J. Vocat. Behav. 2019, 112, 396-416. [CrossRef]

94. Hsieh, H.H.; Huang, J.T. The effects of socioeconomic status and proactive personality on career decision self-efficacy. Career Dev. Q. 2014, 62, 29-43. [CrossRef] 